\title{
Universiteit
}

Leiden

The Netherlands

\section{Militaire gezondheidszorg: geïntegreerde zorg en gedesintegreerde rechten van de patiënt?}

Hendriks, A.C.

\section{Citation}

Hendriks, A. C. (2007). Militaire gezondheidszorg: geïntegreerde zorg en gedesintegreerde rechten van de patiënt? Tijdschrift Voor Gezondheidsrecht, 100-109. Retrieved from https://hdl.handle.net/1887/14088

Version: $\quad$ Not Applicable (or Unknown)

License: $\quad$ Leiden University Non-exclusive license

Downloaded from: https://hdl.handle.net/1887/14088

Note: To cite this publication please use the final published version (if applicable). 
Bijdrage

\title{
Harmonisatie militaire gezondheidszorg. Een zorg meer of minder?
}

door

\author{
Prof.mr. A.C. Hendriks ${ }^{1}$
}

\section{Inleiding}

De Zorgverzekeringswet $(\mathrm{Zvw})^{2}$ heeft per 1 januari 2006 een einde gemaakt aan het tot dan toe bestaande, weinig overzichtelijke verzekeringssysteem voor curatieve gezondheidszorg in Nederland. De Zvw vervangt namelijk de oude ziekenfondsverzekering, de particuliere ziektekostenverzekering en de publiekrechtelijke ziektekostenregelingen voor bepaalde categorieën ambtenaren. Sinds de inwerkingtreding van de Zvw rust op alle Nederlandse ingezetenen ${ }^{3}$ de verplichting met een zorgverzekeraar naar keuze een bij wet omschreven (basis)verzekering tegen ziektekosten af te sluiten. ${ }^{4}$

Vanwege deze en alle andere veranderingen zou men haast vergeten dat militair ambtenaren, een categorie ambtenaren met een eigen ziektekostenregeling, zijn vrijgesteld van de verzekeringsplicht (art. 2 lid 2 Zvw). Voor hen geldt ook na 1 januari 2006 dat zij op grond van hun aanstelling zijn verzekerd voor geneeskundige zorg. Tegenover dit recht op verzekerde zorg staat de verplichting voor militairen in werkelijke dienst gebruik te maken van de zorg aangeboden door of vanwege de hen aangewezen militair geneeskundige diensten. Ook in dit opzicht is de rechtspositie van militairen anders dan burgers die krachtens de Zvw zijn verzekerd voor door of namens hen gemaakte kosten van geneeskundige zorg. De militair geneeskundige diensten zijn tot op heden per krijgsmachtonderdeel verschillend georganiseerd. Zo werken de Militair Geneeskundige Diensten van de Koninklijke Luchtmacht en van de Koninklijke Marine volgens het model waarbij de huisarts- en bedrijfsgeneeskundige zorg zijn geïntegreerd. De Militair Geneeskundige Dienst van de Koninklijke Landmacht kent daarentegen, althans onder niet-operationele omstandigheden, een scheiding van huisarts- en bedrijfsgeneeskundige zorg. ${ }^{5}$ Het bij de Koninklijke Landmacht bestaande zorgsysteem lijkt van deze drie krijgsmachtonderdelen aldus het meest op het systeem van de civiele gezondheidszorg, waarbinnen de scheiding tussen behandeling en controle een belangrijke plaats inneemt.

Als het aan de Minister van Defensie ligt behoren deze verschillen tussen de krijgsmachtonderdelen binnenkort tot het verleden. Nadat in de Defensienota 2000 een

\footnotetext{
${ }^{1}$ Bijzonder hoogleraar gezondheidsrecht aan de Universiteit Leiden. De auteur is eerder door ACOM en AFMP gevraagd over de onderhavige materie te adviseren.

${ }^{2}$ Wet van 16 juni 2005 , houdende regeling van een sociale verzekering voor geneeskundige zorg ten behoeve van de gehele bevolking, Stb. 2005, 358 en Stb. 2006, 79.

${ }^{3}$ De Zvw heeft daarnaast gevolgen voor buiten Nederland woonachtige AOW-gerechtigden. Vgl. de kortgedingprocedure aangespannen door een groep pensionados tegen de Staat der Nederlanden over de wettelijke bijdrage die moest worden betaald, Vzr. Rb. 's-Gravenhage 31 maart 2006, Gezondheidszorg Jurisprudentie 2006, 42.

${ }^{4}$ Strikt genomen geldt deze verplichting voor eenieder die krachtens de Algemene wet bijzondere ziektekosten (AWBZ) van rechtswege is verzekerd tegen bijzondere ziektekosten. Art. 2 lid 1 Zvw.

${ }^{5}$ De wijze waarop de geneeskundige zorg van de Koninklijke Marechaussee is georganiseerd blijft in deze bijdrage buiten beschouwing.
} 
nieuwe strategische visie op de militaire gezondheidszorg was aangekondigd, ${ }^{6}$ heeft de minister op 16 december 2003 besloten tot krijgsmachtbrede invoering van een systeem van geïntegreerde eerstelijnsgezondheidszorg. Dit systeem zal, zo beoogt de minister, samen met een aantal andere wijzigingen op het gebied van de arbeidsvoorwaarden juridisch zijn beslag gaan krijgen in de Militaire Ambtenarenwet 1931 (MAW). De Minister van Defensie voert hierover thans overleg met de centrales van overheidspersoneel in het Sectoroverleg Defensie. $^{7}$

De verschillen tussen de civiele en militaire gezondheidszorg worden door de invoering van een eerstelijns geïntegreerd curatief-bedrijfsgeneeskundig zorgmodel geaccentueerd. ${ }^{8}$ In onderstaande bijdrage wordt nagegaan of dit wenselijk is, meer in het bijzonder of de daartoe aangedragen redenen rechtens standhouden, nu - zoals zal worden betoogd - binnen een dergelijk bestel de rechten van patiënten (militair ambtenaren) en de professionele standaard van zorgverleners (militair artsen) onder druk komen te staan. Om een en ander te verduidelijken volgt hieronder allereerst een schets van het juridische kader waarbinnen gezondheidszorg wordt geleverd $(\S 2)$ en de - voor het onderhavige onderwerp - belangrijkste overeenkomsten en verschillen tussen de systemen van civiele en militaire gezondheidszorg (§ 3). Aansluitend ga ik in op de voorgestelde systeem van militaire gezondheidszorg (§ 4) en de gevolgen hiervan voor militairen en militair artsen $(\S 5)$. Het geheel sluit ik af met een beoordeling $(\S 6)$ en samenvattende conclusies $(\S 7)$.

\section{$2 \quad$ Juridisch kader}

Ingevolge artikel 22, eerste lid, van de Grondwet (Gw) en soortgelijke bepalingen in diverse verdragen waarbij Nederland partij is, is de overheid gehouden maatregelen te nemen ter verwezenlijking van het recht op gezondheid, waaronder het waarborgen van een systeem van zorg dat voldoet aan de eisen van beschikbaarheid, toegankelijkheid, acceptabel en voldoende kwaliteit. ${ }^{9}$ Krachtens de jurisprudentie van het Europees Hof voor de rechten van de mens (EHRM) geldt de verplichting van de overheid tot het verzekeren van de gezondheid en het welzijn van mensen in het bijzonder ten opzichte van personen in een afhankelijke situatie, zoals gedetineerden, ${ }^{10}$ minderjarigen ${ }^{11}$ en militairen. ${ }^{12}$

Hiermee is niet gezegd dat de overheid zelf zorg moet dragen voor een alomvattend systeem van gezondheidszorg. Het staat de overheid vrij het aanbieden van gezondheidszorg over te laten aan particulieren. De overheid dient evenwel te verzekeren dat 'privatization of the health sector does not constitute a threat to the availability, accessibility, acceptability and quality of health facilities, good and services. ${ }^{13}$ Uit dit laatste spreekt dat op de overheid de eindverantwoordelijkheid rust - en blijft rusten - voor het verwezenlijken van de doelstellingen die liggen besloten in het recht op gezondheid. Dit verklaart waarom de Zvw

\footnotetext{
${ }^{6}$ Kamerstukken II 1999/2000, 26 900, nr. 2, p. 90.

${ }^{7}$ Vgl. Kamerstukken II 2005/06, 30300 X, nr. 68.

${ }^{8}$ Over deze overeenkomsten en verschillen, zie reeds M.A.J. van Diest, 'Gezondheidsrecht en Defensie', MRT 2000, p. 353-364.

${ }^{9}$ Over de relatie tussen het recht op gezondheid en het systeem van gezondheidszorg, zie bijv. B.C.A. Toebes, The Right to Health as a Human Right in International Law (diss. Utrecht), Antwerpen: Intersentia 1999, p. 1620.

${ }^{10}$ EHRM 26 oktober 2000, Kudla t. Polen (GC), NJ 2001, 594 (m.nt. E.A. Alkema), NJCM-Bulletin 2001, p. 71 (m.nt. T. Barkhuysen) en EHRM 14 november 2002, Mouisel t. Frankrijk, EHRC 2003, 2 (m.nt. G. de Jonge).

${ }^{11}$ EHRM 10 mei 2001, Z. e.a. t. het VK (GC), EHRC 2001, 46 (m.nt. E. Brems).

${ }^{12}$ EHRM 7 juni 2005, Kılınç e.a. t. Turkije, nr. 40145/98. Deze zaak betrof de zelfmoord van een militair, waarvan bekend was dat hij psychische klachten had.

${ }^{13}$ VN-Comité inzake Economische, Sociale en Culturele Rechten, General Comment 14: The right to the highest attainable standard of health, E/C.12/2000/4 (11 augustus 2000), § 35.
} 
tal van publiekrechtelijke waarborgen bevat om te verzekeren dat basis gezondheidszorg voor eenieder toegankelijk blijft.

Particulieren spelen in Nederland vanouds een sleutelrol bij het aanbieden van

gezondheidszorg. In de loop der jaren zijn er hier te lande tal van regels tot stand gekomen die de handelwijze normeren van (natuurlijke en rechts)personen die zich, in het kader van de uitoefening van een geneeskundig beroep of bedrijf, inlaten met handelingen op het gebied van de geneeskunst. Deze regelingen beogen zowel de kwaliteit van de gezondheidszorg als het respect voor de rechten van de zorgvrager te waarborgen en trachten ook anderszins bij te dragen aan het verwezenlijken van het recht op gezondheid.

Voor de onderhavige problematiek zijn de volgende patiënten- en kwaliteitswetten in het bijzonder van belang:

- de Wet op de geneeskundige behandelingsovereenkomst (WGBO) ${ }^{14}$, een algemene regeling inzake de patiëntenrechten, geïncorporeerd in het Burgerlijk Wetboek (BW);

- de Wet op de beroepen in de individuele gezondheidszorg (Wet BIG), ${ }^{15}$ een kwaliteitswet, die de patiënt beoogt te beschermen tegen ondeskundig en onzorgvuldig handelen door een individuele beroepsbeoefenaar ${ }^{16}$;

- de Arbeidsomstandighedenwet 1998 (Arbo-wet) ${ }^{17}$, een wet die ziet op de veiligheid en de gezondheid van het werk alsmede de begeleiding van zieke werknemers, op grond waarvan de werkgever zich met betrekking tot bepaalde taken moet laten bijstaan door deskundigen, waaronder bedrijfsartsen; en

- de Wet bescherming persoonsgegevens (WBP) ${ }^{18}$, een (algemene) privacywet, die ziet op de verwerking van persoonsgegevens, waaronder het gebruik van gegevens inzake de gezondheid van een persoon.

De in deze en andere patiënten- en kwaliteitswetten opgenomen regels, soms nader uitgewerkt in gedragscodes, protocollen en andere instrumenten van zelfregulering, zijn in beginsel integraal van toepassing op de zorgverlening aan militairen alsmede op de privaat- en publiekrechtelijke (natuurlijke en rechts)personen die hierbij zijn betrokken, waaronder militair artsen. Bovengenoemde patiënten- en kwaliteitswetten laten in beperkte mate ruimte om van de hierin opgenomen regels af te wijken. ${ }^{19}$ Deze afwijkingen moeten, zeker voor zover daarbij inbreuk wordt gemaakt op de rechten en fundamentele vrijheden van individuen, voldoen aan de eisen van wet- en rechtmatigheid, legitimiteit en noodzakelijkheid. De noodzakelijkheid van een inbreuk is afhankelijk van de instrumentaliteit, subsidiariteit en proportionaliteit van het middel. Deze eisen worden strenger getoetst naarmate de te beschermen groep personen zich in een kwetsbaarder positie bevindt.

In dit verband is van belang dat afwijkingen van de in patiënten- en kwaliteitswetten opgenomen normen niet altijd kunnen worden gerechtvaardigd met een beroep op de toestemming van betrokkene. Zo kan niet ten nadele van de patiënt worden afgeweken van de regels van de WGBO (art. 7:468 BW) en is een hulpverlener te allen tijde gehouden de zorg van een goed hulpverlener in acht te nemen (art. 7:453 BW). Dit komt overeen met het uitgangspunt dat grondrechten, die in de gezondheidszorg vaak in het geding zijn, onvervreemdbaar zijn.

Voor zover de hulpverlener staat geregistreerd als arts, tandarts, verpleegkundige of een ander door artikel 3 Wet BIG gereguleerd beroep kan hij voor zijn handelwijze tuchtrechtelijk

\footnotetext{
${ }^{14}$ Stb. 1994, 838 .

${ }^{15}$ Stb. 1993, 65.

${ }^{16}$ De evenknie van de in art. 40 Wet BIG neergelegde verplichting tot het bieden van verantwoorde zorg voor instellingen vormt de Kwaliteitswet zorginstellingen (KZI), Stb. 1996, 80.

${ }^{17}$ Stb. 1999, 184.

${ }^{18}$ Stb. 2000, 302

${ }^{19}$ Bijvoorbeeld ingeval uit de wetsgeschiedenis of de wetsystematiek volgt dat deze op een bepaalde situatie niet van toepassing zijn dan wel krachtens een lex specialis.
} 
aansprakelijk worden gesteld, waarbij hij zich niet kan verschuilen achter de toestemming van de patiënt of opdrachten van een werkgever. Illustratief in dezen zijn de uitspraken van het Regionaal Tuchtcollege voor Gezondheidszorg te Amsterdam in de zaken tegen de hulpverleners van Sylvia Millecam. Het college maakte korte metten met het verweer van de aangeklaagde artsen, stellende dat Millecam behandeling weigerde en zich niet volgens de richtlijnen wenste te laten behandelen. ${ }^{20}$

\section{3 (Organisatie van de) gezondheidszorg}

Uit het voorgaande volgt dat de patiënten- en kwaliteitswetten in beginsel integraal van toepassing zijn op zowel de civiele als militaire gezondheidszorg. Doordat beide systemen op andere wijze zijn georganiseerd, roept de naleving van deze normen binnen het systeem van militaire gezondheidszorg soms specifieke knelpunten op, temeer nu het voornemen bestaat de eerstelijns huisarts- en bedrijfsgeneeskundige zorg te integreren.

\section{Civiele gezondheidszorg}

De civiele gezondheidszorg wordt gekenmerkt door een scheiding tussen behandeling (incl. advies, diagnostiek en care) en controle (waaronder begeleiding, reïntegratie en afschatting). De - toenmalige - Nederlandse Maatschappij tot Bevordering van de Geneeskunst ${ }^{21}$ heeft deze scheiding in 1888 aangebracht. De organisatie en financiering van de behandelende en controlerende sector zijn sindsdien op andere leest gestoeld. Zo ziet de eerder aangehaalde Zvw enkel op de curatieve gezondheidszorg en worden de bedrijfsgezondheidszorg en verzekeringsgeneeskunde, zoals vanouds, bekostigd door werkgevers, werknemers en inkomensverzekeraars. In het verlengde hiervan hebben curatief werkende artsen (huisartsen en specialisten) en niet-curatief werkende artsen (waaronder bedrijfs- en verzekeringsartsen) verschillende taken en bevoegdheden.

Directe aanleiding voor deze - internationaal gezien unieke - scheiding tussen behandeling en controle vormden de zogenaamde ziektebriefjes. De scheiding werd voorts wenselijk geacht met het oog op de onafhankelijke beoordeling van de patiënt/zieke werknemer/verzekerde in verband met de toekenning van een eventuele uitkering en ter waarborging van de vertrouwensrelatie tussen (behandelend) arts en patiënt.

Dit stelsel geldt in Nederland tot op de dag van vandaag. Hoewel de adequate behandeling, de begeleiding en de reïntegratie van zieke werknemers soms lijken te worden bemoeilijkt door de gescheiden verantwoordelijkheden tussen curatieve en niet-curatieve artsen (incl. de scheiding tussen bedrijfsgeneeskundige en verzekeringsgeneeskundige zorg), ${ }^{22}$ bestaat hiervoor ruime steun. Het wordt tevens als beste waarborg gezien voor de onafhankelijke beoordeling van zieke werknemers/verzekerden en voor het respect voor de rechten van de patiënt. Via (het werken volgens) standaarden en protocollen wordt getracht gesignaleerde afstemmingsproblemen te verhelpen. ${ }^{23}$

Deze scheiding heeft ook invloed op de van toepassing zijnde wet- en regelgeving. De regels van de eerder aangehaalde WGBO zien primair op behandelingsrelaties. De patiënt treedt hierbij juridisch gezien op als opdrachtgever. Handelingen op het gebied van de geneeskunst

\footnotetext{
${ }^{20}$ RTG Amsterdam 7 april 2006, Medisch Contact 2006, p. 672.

${ }^{21}$ Thans Koninklijke Nederlandse Maatschappij tot Bevordering van de Geneeskunst (KNMG).

${ }^{22}$ HR 23 juni 2000, JAR 2000, 164, een zaak waarin de huisarts en bedrijfsarts andere adviezen gaven.

${ }^{23}$ Bij wijze van voorbeeld kan worden gewezen op het Convenant tussen de Landelijke huisartsenvereniging (LHV) en de Nederlandse vereniging voor arbeids- en bedrijfsgeneeskunde (NVAB) inzake samenwerking bij sociaal-medische begeleiding (1997) en KNMG-Code samenwerking bij arbeidsverzuim (1998).
} 
in opdracht van de patiënt worden wel aangemerkt als vrijwillige handelingen; de patiënt heeft dit zelf zo gewild. Bij geneeskundige handelingen anders dan krachtens een behandelingsovereenkomst - hierna: opdrachthandelingen ${ }^{24}$ - zijn de bepalingen van de WGBO slechts van overeenkomstige toepassing voor zover de aard van de rechtsbetrekking zich daartegen niet verzet (art. 7:464 BW). De overeenkomstige toepassing kan ook door middel van wetgeving zijn uitgesloten (vgl. 14 lid 6 Arbo-wet).

De scheiding tussen behandeling en controle impliceert onder meer dat een behandelend arts de toestemming nodig heeft van zijn patiënt voor het doorgeven van gegevens aan diens bedrijfsarts. De bedrijfsarts, die een belangrijke rol vervult bij de sociaal-medische begeleiding en reïntegratie van zieke werknemers, wordt in juridische zin immers niet aangemerkt als medebehandelaar, in welk geval toestemming van de patiënt mag worden verondersteld (art. 7:457 lid 2 BW), maar als derde. De omstandigheid dat bedrijfsartsen sinds 2004 de mogelijkheid hebben werknemers met een arbeidsrelevante aandoening rechtstreeks te verwijzen doet hieraan niet af. Dezelfde regels gelden met betrekking tot verzekeringsartsen. Voor het uitwisselen van gegevens tussen behandelend artsen en verzekeringsartsen alsmede tussen bedrijfs- en verzekeringsartsen onderling geldt in beginsel eveneens het toestemmingsbeginsel, al is in de jurisprudentie uitgemaakt dat het doen van een beroep op de sociale zekerheid een rechtvaardiging kan vormen voor een inperking van de (informationele) privacy. Hierbij is van belang dat deze informatie wordt verstrekt aan een persoon die zelf ook is gebonden aan een beroepsgeheim. ${ }^{25}$

Voor zover bedrijfsartsen - al dan niet door middel van tussenkomst van een (externe) Arbodienst - werkzaamheden verrichten in opdracht van een werkgever, zijn zij gehouden aan de werkgever verslag uit te brengen in de vorm van rapportages en adviezen. ${ }^{26} \mathrm{Bij}$ het uitvoeren van deze taken zijn bedrijfsartsen evenwel gehouden de privacy van de werknemer te respecteren en ook anderszins te handelen op een wijze die verenigbaar is met de (ook) op bedrijfsartsen rustende geheimhoudings- en zorgvuldigheidsplicht. Dit laatste verplicht de bedrijfsarts - ook al is hij werknemer van de werkgever/externe Arbo-dienst - tot het betrachten van de grootst mogelijke mate van zorgvuldigheid bij het verslag uitbrengen aan de werkgever en het geven van adviezen in het kader van de sociaal-medische begeleiding en reïntegratie. ${ }^{27}$ Dit spreekt ook uit de Arbo-wet. Deze wet bevat zowel een verplichting voor de werkgever om deskundige werknemers in de gelegenheid te stellen 'de bijstand' zelfstandig en onafhankelijk te verrichten, als ook een verplichting voor deze deskundigen zelf waaronder bedrijfsartsen - bijstand te verlenen met behoud van hun zelfstandigheid en hun onafhankelijkheid (zie art. 13-14 Arbo-wet). Zelfstandigheid en onafhankelijkheid impliceren dat de professionele standaard leidend is voor de handelwijze van de betrokken hulpverleners, waaronder het nakomen van de rechten van de patiënt. ${ }^{28}$ Tegelijkertijd heeft de wetgever met betrekking tot de begeleiding van zieke werknemers erkend dat de geheimhoudingsplicht (art. 7:457) en het blokkeringsrecht van de patiënt (art. 7:464 lid 2 onder b BW) niet van overeenkomstige toepassing kunnen worden verklaard, daar dit in de weg zou kunnen staan aan goede sociaal-medische begeleiding en de plichten en verantwoordelijkheden die terzake op de werkgever rusten (art. 14 lid 6 Arbo-wet). ${ }^{29}$ A contrario zou hieruit kunnen worden

\footnotetext{
${ }^{24}$ Het betreft geneeskundige handelingen in opdracht van een ander dan de patiënt, zoals de werkgever of een uitvoeringsinstelling.

${ }^{25}$ Vgl. EHRM 27 augustus 1997, Andersson t. Zweden, NJ 1999, 463 (m.nt. J.C.J. Dute, onder nr. 464), NJCMBulletin 1998, p. 164 (m.nt. A.C. Hendriks) en 27 augustus 1997, M.S. t. Zweden, NJ 1999, 464 (m.nt. J.C.J. Dute), NJCM-Bulletin 1998, p. 164 (m.nt. A.C. Hendriks).

${ }^{26}$ CTG 2 januari 2002, TvGR 2002, 23.

${ }^{27}$ CTG 11 januari 2001, TvGR 2001, 9 en RTG Amsterdam 10 mei 2005, TvGR 2005, 42.

${ }^{28}$ H.J.J. Leenen \& J.K.M. Gevers, Handboek gezondheidsrecht (deel II), Houten / Diegem: Bohn Stafleu Van Loghum 2002, p. 43 e.v.

${ }^{29}$ Stb. 2000, 121.
} 
geconcludeerd dat de overige rechten van de patiënt wel integraal dienen te worden nageleefd bij de begeleiding tijdens ziekte van de werknemer.

Volledigheidshalve dient hierbij te worden opgemerkt dat een bedrijfsarts niet altijd als opdrachtnemer van de werkgever, maar soms ook als opdrachtnemer van de werknemer fungeert. Er is dan sprake van vrijwillige handelingen, waarbij gedacht kan worden aan een werknemer die zich wendt tot het arbeidsomstandighedenspreekuur of eigener beweging curatieve handelingen ondergaat. Op dergelijke situaties is de WGBO - en de hierin neergelegde geheimhoudingsplicht (art. 7:457 lid $1 \mathrm{BW}$ ) - rechtstreeks en integraal van toepassing. Verdedigd kan worden dat de WGBO, in ieder geval bij strikte lezing van deze wet, de bedrijfsarts verplicht een scheiding aan te brengen tussen informatie verkregen bij vrijwillige handelingen en informatie verkregen bij opdrachthandelingen - waaronder aanstellingskeuringen, verplichte keuringen tijdens dienstverband en handelingen uitgevoerd in het kader van de sociaal-medische begeleiding van een zieke werknemer - wil de bedrijfsarts niet in strijd handelen met deze verplichting (en het daarmee corresponderende recht op privacy van de werknemer).

\section{Militaire gezondheidszorg}

De gezondheidszorg aan de zee-, land- en luchtstrijdkrachten is vanouds anders georganiseerd dan de civiele gezondheidszorg. Dit hangt samen met de bijzondere positie en taken van de krijgsmacht in onze samenleving en het belang van de operationele inzetbaarheid van de strijdkrachten. ${ }^{30}$ Vanwege deze speciale context is een systeem van militaire gezondheidszorg opgezet met een tweeledige behoefte doelstelling: het bieden van geneeskundige verzorging in het belang van de militair alsmede in het belang van zijn inzetbaarheid. ${ }^{31}$ Hieruit volgt reeds dat er geen strikte scheiding wordt gemaakt tussen curatieve en bedrijfsgeneeskundige gezondheidszorg, nu beide geacht worden nauw met elkaar te zijn verbonden. Daar komt bij dat tot voor enige tijd algemeen werd aangenomen dat op de defensieorganisatie een levenslange en exclusieve zorgverantwoordelijkheid rust. Zoals bekend is in de Defensienota 2000 aangekondigd de arbeidsvoorwaarden van militairen aan te passen aan de eisen van deze tijd en zoveel mogelijk in overeenstemming te brengen met hetgeen elders in de maatschappij gebruikelijk is. ${ }^{32}$ Hierdoor wordt deze zorgverantwoordelijkheid genuanceerd.

De eerder aangehaalde patiënten- en kwaliteitswetten stellen dusdanige eisen aan het handelen van de arts, dat zij in de optiek van de legerleiding in de weg staan aan de effectieve taakvervulling. Om die reden is van de zijde van Defensie bij de totstandkoming van de WGBO betoogd dat deze wet niet integraal van toepassing kan zijn op de militaire gezondheidszorg. Wel is het altijd de bedoeling geweest dat de normen van de WGBO en andere patiënten- en kwaliteitswetten zoveel mogelijk overeenkomstig toepassing zouden vinden, tenzij de aard van de rechtsbetrekking - waaronder de taken van de krijgsmacht en het belang van de inzetbaarheid van de strijdkrachten - zich hiertegen zou verzetten. De precieze betekenis van in patiënten- en kwaliteitswetten neergelegde normen zouden in beroepscodes

\footnotetext{
${ }^{30}$ Krachtens art. $97 \mathrm{Gw}$ is er een krijgsmacht ter verdediging en bescherming van de belangen van het koninkrijk en de handhaving en de bevordering van de internationale rechtsorde. De Defensienota 2000 onderscheidt daarnaast, als derde taak, de ondersteuning van civiele autoriteiten bij rechtshandhaving, rampenbestrijding en humanitaire hulp, zowel nationaal als internationaal. Kamerstukken II 1999/2000, 26 900, nr. 2, p. 41.

${ }^{31} \mathrm{Vgl}$. art. 91 van het Algemeen militair ambtenarenreglement (AMAR): 'De geneeskundige verzorging verleend door of vanwege de militair geneeskundige dienst omvat al de maatregelen, voorzieningen en geneeskundige verstrekkingen in het belang van de bescherming, het behoud, het herstel en de bevordering van de gezondheid van de militair alsmede in het belang van de bescherming, het behoud, het herstel en de bevordering van de geschiktheid van de militair voor de dienst (art. 91 AMAR).

${ }^{32}$ Kamerstukken II 1999/2000, 26 900, nr. 2, p. 84.
} 
nader kunnen worden uitgewerkt, al dan niet in overleg met de KNMG of andere beroepsgroepen op te stellen.

Zoals eerder opgemerkt was de geneeskundige zorg tot nu toe per krijgsmachtonderdeel georganiseerd. ${ }^{33}$ Het ligt in de bedoeling om de wijze waarop de Militair Geneeskundige Diensten bij de Koninklijke Luchtmacht en bij de Koninklijke Marine thans werken, te weten een werkwijze waarbij de huisarts- en bedrijfsgeneeskundige zorg zijn geïntegreerd, krijgsmachtbreed in te voeren. Deze zorgharmonisatie zal dus in het bijzonder gevolgen hebben voor militair ambtenaren en militair artsen werkzaam bij de Koninklijke Landmacht, al zullen ook aanpassingen nodig zijn bij de andere krijgsmachtonderdelen.

Anders dan in de Defensienota 2000 wordt aangekondigd wordt met de keuze voor integratie van de huisarts- en bedrijfsgeneeskundige zorg (meer) afstand genomen van hetgeen elders in de maatschappij gebruikelijk is. Immers, de scheiding tussen behandeling en controle maakt kernbestanddeel uit van het stelsel van civiele gezondheidszorg. Dit roept de vraag op naar de beweegredenen voor de harmonisatie van de militaire gezondheidszorg en de (juridische) implicaties.

\section{$4 \quad$ Het voorgestelde systeem van militaire gezondheidszorg}

\section{Aanleiding}

De krijgsmacht vervult thans een andere rol dan ten tijde van de totstandkoming van de MAW (1931). De veranderingen betreffen ondermeer de toegenomen operationele taakstelling en het frequente optreden in internationale missies. Daarnaast werken de verschillende krijgsmachtonderdelen steeds meer samen. Deze wijzigingen pleiten volgens de Minister van Defensie voor een harmonisatie en andere organisatie van de militaire gezondheidszorg. ${ }^{34}$ Een systeem van militaire gezondheidszorg dat per krijgsmachtonderdeel op andere leest is geschoeid, kan in de weg staan aan nauwere samenwerking. Vanuit dit gezichtpunt laat het streven naar harmonisatie zich eenvoudig verklaren. De keuze voor een geïntegreerd stelsel van huisarts- en bedrijfsgeneeskundige zorg wordt bovenal ingegeven door redenen van efficiency en wordt geacht in het belang te zijn van de operationele inzetbaarheid van de krijgsmacht. De nieuwe rol en taken van de krijgsmacht vragen erom, aldus de concept memorie van toelichting bij de wijziging van de WAM van 8 maart 2006, dat te allen tijde inzicht bestaat in de inzetbaarheid van het personeel van de krijgsmacht. Het wordt voorts wenselijk geacht dat de militair arts, zonodig zonder toestemming van de militair, gevraagd en ongevraagd advies uitbrengt over de vraag of de inzet van een militair gevaar met zich brengt voor zijn gezondheid, de veiligheid van anderen of de operationele inzet. Daartoe is, aldus de concept memorie van toelichting, ook nodig dat de militair arts vrijelijk kan beschikken over de informatie uit het medisch dossier van de militair.

\section{Inhoud van voorgestelde regeling}

Een blauwdruk van het nieuwe zorgmodel is, zij het zeer summier, neergelegd in het conceptartikel 12h MAW. Het concept-artikel 12h MAW behelst evenwel meer dan een harmonisatie van de verschillende zorgsystemen volgens het model van een eerstelijns curatiefbedrijfsgeneeskundige zorg. Op grond van dit artikel is een militair onder meer gehouden

\footnotetext{
${ }^{33}$ Zo werken de Koninklijke Landmacht en Koninklijke Luchtmacht met gezondheidscentra en de Koninklijke Marine met ziekenboegen.

${ }^{34}$ Voor meer achtergrondinformatie zie o.a. de voordracht van Cdre A.J. van Leusden, Zorgharmonie, Voorlichting aan het geneeskundig personeel van de KL, 30 januari 2004.
} 
- gebruik te maken van de militaire gezondheidszorg (lid 1);

- (bij ziekte) zich te houden aan de voorschriften van de verantwoordelijke miltair arts (lid 2); en

- zich in opdracht van de Minister te onderwerpen en zijn medewerking te verlenen aan een geneeskundig of tandheelkundig onderzoek (lid 4).

Voorts zal er sprake zijn van een geïntegreerd militair geneeskundig dossier, dat zowel huisarts- als bedrijfsgeneeskundige gegevens bevat betreffende de militair. Naast militair artsen zullen andere leden van het medisch zorgteam gebruik kunnen maken van dit eerstelijns curatief bedrijfsgeneeskundig dossier op basis van het principe van vrije geneeskundige informatie-uitwisseling (lid 5).

Dit concept-artikel bepaalt voorts dat 'een daartoe aangewezen militair arts van het medisch zorgteam de commandant desgewenst of op eigen initiatief en ongeacht de toestemming [adviseert] over diens inzetbaarheid' (lid 6).

Voor wat betreft de verwerking van persoonsgegevens en medische gegevens betreffende de gezondheid van militairen is tot slot bepaald dat hieromtrent bij AMvB regels worden gesteld (lid 7).

\section{Gevolgen van het voorgestelde systeem voor militairen en militair artsen}

Deze om redenen van efficiency en ter verzekering van de inzetbaarheid van militairen voorgestelde wijzigingen hebben vergaande gevolgen voor de (rechts)positie van militairen en militair artsen.

\section{Militairen}

Het voorgestelde artikel 12h MAW doet de bij de Koninklijke Landmacht bestaande scheiding tussen behandeling en controle teniet. De militaire zorgteams (MZTs) zullen namelijk zowel huisartsgeneeskundige als bedrijfsgeneeskundige zorg bieden. Voorts bevat deze bepaling de verplichting voor de militair ambtenaar in werkelijke dienst 'zich tot het voor hem aangewezen medisch zorgteam te wenden ter verkrijging van gezondheidszorg' (concept-art. 12h lid $1 \mathrm{MAW}$ ). Dit betekent een duidelijke accentverschuiving ten opzichte van het huidige Algemeen militair ambtenarenreglement (AMAR). Is de aanspraak op vergoeding van kosten gemaakt voor geneeskundige verzorging in het AMAR bovenal als recht geformuleerd (art. 90a AMAR), in het voorgestelde artikel 12h MAW staan de verplichtingen van de militair centraal, waaronder de plicht geneeskundige zorg af te nemen van zijn MZT, meer in het bijzonder van zijn verantwoordelijk militair arts (VMA). Daarnaast is een militair in werkelijk dienst ondermeer verplicht 'zich te onderwerpen aan en zijn medewerking te verlenen aan een geneeskundig of tandheelkundig onderzoek door of vanwege het voor hem aangewezen medisch zorgteam' (concept-art. 12h lid $3 \mathrm{MAW}$ ) en 'zich te onderwerpen aan en zijn medewerking te verlenen aan een geneeskundig of tandheelkundig onderzoek indien Onze Minister [daartoe] op goede gronden van oordeel is'(concept-art. 12h lid 4 MAW). ${ }^{35}$ Daar komt bij, en anders dan thans, dat alle huisarts- als bedrijfsgeneeskundige gegevens betreffende de militair worden opgenomen in het geïntegreerd militair geneeskundig dossier, dat deze informatie toegankelijk is voor alle leden van het MZT en dat de VMA, dan wel ieder ander lid van het MZT die contact heeft met een militair, te allen tijde let op de inzetbaarheid van de militair en de commandant hierover in voorkomende gevallen informeert.

\footnotetext{
${ }^{35}$ Volledigheidshalve dient te worden opgemerkt dat het AMAR soortgelijke verplichtingen bevat voor militairen (vgl. art. 92-105 AMAR).
} 


\section{Militair artsen}

Het voorgestelde artikel 12h MAW maakt het voor militair artsen moeilijk hun beroep uit te oefenen op een wijze die geheel verenigbaar is met de voor artsen bestaande normen. De voorgestelde bepaling bevat voor militair artsen immers tal van verplichtingen die moeilijk zijn te verenigen met de professionele standaard van huis- en bedrijfsartsen, waaronder de verplichting tot het respecteren van de rechten van de patiënt. Zo vormt het medisch beroepsgeheim niet slechts de keerzijde van het recht op privacy van de patiënt, maar dient het ook ter waarborging van de toegankelijkheid van de zorg. Op grond van het voorgestelde artikel 12h MAW worden militair artsen verplicht allerlei medische gegevens, via het geïntegreerd militair geneeskundig dossier, te delen met anderen, waaronder personen die niet of slechts ten dele als medebehandelaars kunnen worden aangemerkt. Het medisch beroepsgeheim en het recht op privacy van de patiënt worden verder op de proef gesteld nu militair artsen 'desgevraagd dan wel op eigen initiatief en ongeacht de toestemming van de militair' geacht worden de commandant van de militair te informeren over de inzetbaarheid van laatstgenoemde (concept-art. 12h lid $6 \mathrm{MAW}$ ). Deze verplichting respectievelijk uitnodiging om het medisch beroepsgeheim te doorbreken gaat verder dan op grond van het leerstuk van conflict van plichten doorgaan toelaatbaar wordt geacht. ${ }^{36}$

De omstandigheid dat een militair arts twee functies in zich verenigt en als militair ambtenaar ondergeschikt is aan zijn leidinggevende maakt een en ander niet anders. Een militair arts staat als arts geregistreerd in het BIG-register (en daarnaast evt. als huis- en/of bedrijfsarts in het door de KNMG beheerde specialistenregister). Deze registratie betekent niet alleen dat hij gerechtigd is de (huis- dan wel bedrijfs)artsentitel te voeren, maar impliceert tevens gehoudenheid aan de professionele standaard van artsen en aanvaarding van het medisch tuchtrecht. De instructie door een leidinggevende laat de eigen verantwoordelijkheid van de arts voor de kwaliteit van de beroepsuitoefening en de naleving van de rechten van de patiënt onverlet, een verantwoordelijkheid waarop de arts niet alleen tuchtrechtelijk maar ook civielen strafrechtelijk kan worden aangesproken.

\section{$6 \quad$ Beoordeling}

De patiënten- en kwaliteitswetgeving zijn er ter bescherming van de (rechten van de) patiënt en ter waarborging van de kwaliteit van de beroepsuitoefening. De verantwoordelijkheid van de overheid tot het verzekeren van de gezondheid en het welzijn van personen geldt, volgens jurisprudentie van het EHRM, in het bijzonder ten opzichte van kwetsbare groepen, waaronder militairen. ${ }^{37}$ Vanuit dit licht bezien kan niet anders dan worden geconcludeerd dat het voorgestelde militaire zorgsysteem een aantal forse beperkingen met zich brengt op de rechten en vrijheden van de militair. Dit geldt zeker in vergelijking tot de wijze waarop anderen in Nederland gebruik kunnen maken van de huisartsgeneeskundige en bedrijfsgeneeskundige zorg en de hen daarbij toekomende rechten. Daar komt bij dat binnen het voorgestelde systeem geen gewicht wordt toegekend aan het elders gebruikelijke onderscheid tussen vrijwillige en opdrachthandelingen.

De inperkingen betreffen in het bijzonder de grondrechten en fundamentele beginselen die aan de patiëntenrechten ten grondslag liggen, zoals het recht op vrije artsenkeuze (in de curatieve sector), het recht op lichamelijke integriteit (op grond waarvan toestemming nodig is voor lichamelijk onderzoek) en allerlei aspecten van het recht op (informationele) privacy.

\footnotetext{
${ }^{36}$ H.J.J. Leenen \& J.K.M. Gevers, Handboek gezondheidsrecht (deel I), Houten / Diegem: Bohn Stafleu Van Loghum 2000, p. 234-235.

${ }^{37}$ Noot 12.
} 
Dit systeem kan ertoe leiden dat militairen geen volledige openheid van zaken verschaffen naar artsen toe en komt, zo moet worden gevreesd, ook anderszins de vertrouwensrelatie tussen militairen en leden van het MZT, waaronder de persoonlijke VMA, niet ten goede. Daar komt bij dat Defensie in dit systeem zowel werkgever als zorgverlener is, waardoor de grens tussen werkgever en zorgaanbieder vloeiend wordt en de ongelijkheid tussen partijen groter.

Niet kan worden gesteld dat het voorgestelde zorgsysteem een rechtstreekse bedreiging vormt voor de kwaliteit van de medische beroepsuitoefening. Tegelijkertijd bevat de voorgestelde wettelijke regeling een aantal bepalingen, dat het militair artsen moeilijk maakt hun beroep uit te oefenen op een wijze die geheel verenigbaar is met de voor hen geldende professionele standaard en die recht doet aan de rechten van de patiënt. Zij kunnen op overtreding van deze normen in rechte persoonlijk worden aangesproken en zich dan niet verschuilen achter hun militaire functie.

$\mathrm{Nu}$ bestaat er geen juridische verplichting tot het waarborgen van een scheiding tussen huisartsgeneeskundige en bedrijfsgeneeskundige zorg. De meeste in de patiënten- en kwaliteitswetten neergelegde normen kennen daarnaast geen absoluut karakter. Afwijking van deze bepalingen is doorgaans mogelijk indien is voldaan aan de eisen van wet- en rechtmatigheid, legitimiteit en noodzakelijkheid.

De vraag is thans of de hierboven beschreven gevolgen en, bezien vanuit de patiënten- en kwaliteitswetgeving, knelpunten van het nieuwe militaire zorgsysteem alle deze rechtvaardigingstoets kunnen doorstaan. In dezen is van belang dat de voorgestelde wijzigingen van het militaire zorgsysteem zijn ingegeven door redenen van efficiency en ter verzekering van de inzetbaarheid van militairen. Efficiencyoverwegingen vormen niet snel een rechtvaardiging voor het maken van inbreuken op grondrechten. Daartoe moet in de regel meer worden gesteld, waarbij de regel al snel streng toetst. Bij een beroep op veiligheidsoverwegingen ligt dit gradueel anders. Rechters zijn gewoon de overheid een ruime, althans ruimere, beleidsruimte te laten bij het beoordelen van de rechtmatigheid en noodzaak van maatregelen met het oog op de nationale veiligheid, waaronder de operationele inzetbaarheid van strijdkrachten. ${ }^{38}$ Hieruit volgt niet dat het veiligheidsargument juridisch bezien een vrijbrief is om iedere inperking van rechten en fundamentele vrijheden van individuen te kunnen rechtvaardigen. ${ }^{39}$ Het omwille van veiligheidsredenen inperken van de rechten van patiënten en onder druk zetten van de professionele standaard van militair (huisen bedrijfs)artsen vraagt om deugdelijke motieven. De van de zijde van Defensie aangedragen argumenten ter onderbouwing van de rechtmatigheid en noodzakelijkheid van de voorgestelde stelselherziening kunnen vooralsnog niet overtuigen en lijken op voorhand een onevenredige inbreuk te maken op de rechten van de patiënt en de professionele standaard van militair (huis- en bedrijfs)artsen. Daarmee kan de voorgestelde wetgevingsoperatie niet de juridische toets doorstaan. Dit impliceert dat het voorliggende wetsvoorstel, althans op basis van de thans aangevoerde motieven ter rechtvaardiging van de invoering van een nieuw militair zorgsysteem, in zijn huidige vorm niet voldoet aan de eisen van wet- en rechtmatigheid, legitimiteit en noodzakelijkheid. Dit probleem kan niet worden ondervangen door toestemming te vragen van betrokkenen daar, zoals betoogd, aldus geen afstand kan worden gedaan van onvervreemdbare rechten en vrijheden.

\footnotetext{
${ }^{38}$ Vgl. HvJ EG 26 oktober 1999, zaak C-273/97 (Sirdar), Jur. 1999, p. I-7403, AB 2000, 70 (m.nt. F.H. van der Burg).

${ }^{39}$ Vgl. HvJ EG 11 januari 2000, zaak C-285/98 (Kreil), Jur. 2000, p. I-69, NJ 2000, 302 (over de uitsluiting van vrouwen voor alle legeronderdelen); EHRM 22 oktober 2002, Perkins \& R. t. het VK, nr. 43208/98 \& 44875/98 alsmede EHRM 22 oktober 2002, Beck, Copp \& Bazeley t. het VK, nr. 48535/99, 48536/99 \& 48537/99 (over de privacy van homoseksuelen in het leger) en EHRM 19 oktober 2005, Roche t. het Verenigd Koninkrijk(GC), EHRC 2005, 118 (over het vertrouwelijke karakter van informatie over experimenten tijdens militaire dienst).
} 


\section{Conclusies}

Krijgsmachtbrede invoering van een systeem van geïntegreerde eerstelijnsgezondheidszorg zorgt voor een verwijdering van het militaire zorgsysteem ten opzichte van het civiele zorgsysteem. Een dergelijk zorgsysteem is voorts vanuit juridisch oogpunt problematisch. Dit geldt temeer indien, zoals thans wordt voorgesteld, de introductie van dit systeem gepaard gaat met regels die anderszins leiden tot het beperken van de rechten van de patiënt en het onder druk zetten van de professionele standaard van militair (huis- en bedrijfs)artsen. Hoewel er geen juridische verplichting bestaat tot het aanbrengen van een scheiding tussen huisartsgeneeskundige en bedrijfsgeneeskundige zorg, vraagt het inperken van fundamentele rechten en het in de weegschaal leggen van de kwaliteit van de medische beroepsuitoefening om valide, steekhoudende argumenten. Zonder afbreuk te willen doen aan het belang van kostenbesparing en de inzetbaarheid van de strijdkrachten kan op grond van deze, nauwelijks nader beargumenteerde, motieven niet worden betoogd dat alle in het concept artikel $12 \mathrm{~h}$ MAW voorgestelde maatregelen juridisch houdbaar zijn. Dit leidt ertoe dat bij gebrek aan nadere onderbouwing dit concept artikel moet worden afgewezen. 